University of Nebraska - Lincoln

DigitalCommons@University of Nebraska - Lincoln

Publications from USDA-ARS / UNL Faculty

U.S. Department of Agriculture: Agricultural

Research Service, Lincoln, Nebraska

2011

Susceptibility of Selected Potato Varieties to Zebra Chip Potato

Disease

Joseph E. Munyaneza

USDA-ARS, joseph.munyaneza@ars.usda.gov

Jeremy L. Buchman

USDA-ARS

Venkatesan G. Sengoda

USDA-ARS

Tonja W. Fisher

USDA-ARS

Cole C. Pearson

USDA-ARS

Follow this and additional works at: https://digitalcommons.unl.edu/usdaarsfacpub

Munyaneza, Joseph E.; Buchman, Jeremy L.; Sengoda, Venkatesan G.; Fisher, Tonja W.; and Pearson, Cole C., "Susceptibility of Selected Potato Varieties to Zebra Chip Potato Disease" (2011). Publications from USDA-ARS / UNL Faculty. 1274.

https://digitalcommons.unl.edu/usdaarsfacpub/1274

This Article is brought to you for free and open access by the U.S. Department of Agriculture: Agricultural Research Service, Lincoln, Nebraska at DigitalCommons@University of Nebraska - Lincoln. It has been accepted for inclusion in Publications from USDA-ARS / UNL Faculty by an authorized administrator of DigitalCommons@University of Nebraska - Lincoln. 


\title{
Susceptibility of Selected Potato Varieties to Zebra Chip Potato Disease
}

\author{
Joseph E. Munyaneza • Jeremy L. Buchman • \\ Venkatesan G. Sengoda • Tonja W. Fisher • \\ Cole C. Pearson
}

Published online: 18 September 2011

(C) Potato Association of America 2011

This article is a U.S. government work, and is not subject to copyright in the United States.

\begin{abstract}
Zebra chip (ZC), an emerging and serious disease of potato has caused millions of dollars in losses to the potato industry in the United States, Mexico, Central America, and New Zealand. The disease has recently been associated with a previously undescribed species of liberibacter tentatively named "Candidatus Liberibacter solanacearum" transmitted to potato by the potato psyllid, Bactericera cockerelli (Šulc). At present, applications of insecticides targeted against the potato psyllid are the only means to manage ZC. Given the low psyllid density and short inoculation access period required to induce the disease, insecticides may not act fast enough to prevent transmission of liberibacter to potato by the psyllid and development of ZC. Identification and development of $\mathrm{ZC}$-resistant or tolerant varieties may offer the most efficient and sustainable way to manage this potato disease. Susceptibility of selected potato varieties to $\mathrm{ZC}$ was evaluated under controlled field cage conditions in 2009 and 2010 in WA by inoculating potato plants with " $\mathrm{Ca}$. L. solanacearum" using infective potato psyllids and monitoring them for ZC symptom development. All potato varieties evaluated in both years of the study were determined to be very susceptible to the disease, with almost $100 \%$ of the inoculated plants developing severe $\mathrm{ZC}$ foliar and tuber symptoms. Potato yield in all tested varieties was significantly affected by $\mathrm{ZC}$, with yield losses ranging from $49.9 \%$ to 87 . $2 \%$. Information from this research
\end{abstract}

J. E. Munyaneza $(\triangle) \cdot J$. L. Buchman • V. G. Sengoda •

T. W. Fisher $\cdot$ C. C. Pearson

USDA-ARS, Yakima Agricultural Research Laboratory,

5230 Konnowac Pass Road,

Wapato, WA 98951, USA

e-mail: joseph.munyaneza@ars.usda.gov suggests that there is an urgent need to develop new potato varieties that are resistant or tolerant to this damaging potato disease.

Resumen Zebra chip (ZC), una enfermedad seria y emergente de papa, ha causado pérdidas por millones de dólares a la industria de la papa en los Estados Unidos, México, América Central y Nueva Zelandia. Se ha asociado a la enfermedad recientemente con una especie no descrita previamente de Liberibacter tentativamente llamada "Candidatus Liberibacter solanacearum", transmitida a la papa por el psílido de la papa Bactericera cockerelli (Šulc). A la fecha, los únicos medios para manejar ZC son las aplicaciones de insecticidas dirigidas contra el psílido de la papa. Considerando la baja densidad del psílido y el corto período de acceso a la inoculación requerido para inducir la enfermedad, los insecticidas tal vez no actúan lo suficientemente rápido para prevenir la transmisión de Liberibacter a papa por el psílido y el desarrollo de ZC. La identificación y desarrollo de variedades resistentes o tolerantes a ZC pudieran ofrecer la forma más eficiente y sostenible para manejar esta enfermedad de la papa. Se evaluó la susceptibilidad a ZC de variedades selectas de papa bajo condiciones controladas de jaulas en el campo en 2009 y 2010 en el Estado de Washington (WA) mediante la inoculación de plantas con "Ca. L. solanacearum" utilizando psílidos de la papa infectivos y dándole seguimiento al desarrollo de síntomas de ZC. Se determinó que todas las variedades de papa evaluadas en los dos años del estudio fueron muy susceptibles a la enfermedad, con casi el $100 \%$ de desarrollo de síntomas severos de ZC en hoja y en tubérculo en las plantas inoculadas. El rendimiento de papa en todas las variedades probadas se afectó significativamente por $\mathrm{ZC}$, con pérdi- 
das variando de 49.9 a $87.2 \%$. La información de esta investigación sugiere que hay una urgente necesidad de desarrollar nuevas variedades de papa que sean resistentes o tolerantes a esta enfermedad dañina en papa.

Keywords Zebra chip disease - Potato · Potato psyllid . Bactericera cockerelli . Liberibacter . Host plant resistance

\section{Introduction}

Zebra chip (ZC), an emerging and serious disease of potato has caused millions of dollars in losses to the potato industry in the United States, Mexico, Central America, and New Zealand, often leading to the abandonment of entire potato fields (Munyaneza et al. 2007a, b, 2008, 2009; Liefting et al. 2008; Secor et al. 2009; Crosslin et al. 2010; Munyaneza 2010; Rehman et al. 2010). The disease has recently been associated with a previously undescribed species of the bacterium liberibacter tentatively named "Candidatus Liberibacter solanacearum" (syn. "Ca. L. psyllaurous") and transmitted by the potato psyllid, Bactericera cockerelli (Šulc) (Munyaneza et al. 2007a, b, 2008; Hansen et al. 2008; Liefting et al. 2008, 2009; Secor et al. 2009; Crosslin et al. 2010; Munyaneza 2010). In the United States, the disease has been documented in several southwestern and central states, including Texas, Nebraska, Colorado, Kansas, Wyoming, New Mexico, Arizona, Nevada, and California (Munyaneza et al. 2007a, b; Secor et al. 2009; Crosslin et al. 2010). ZC is characterized by symptoms that develop in potato tubers, which consist of collapsed stolons, browning of vascular tissue concomitant with necrotic flecking of internal tissues and streaking of the medullary ray tissues, all of which can affect the entire tuber. Upon frying, these symptoms become more pronounced and chips or fries processed from affected tubers show very dark blotches, stripes, or streaks, rendering them commercially unacceptable (Munyaneza et al. 2007a, b, 2008; Secor et al. 2009; Crosslin et al. 2010; Miles et al. 2010). ZC-infected potato plants exhibit a range of aboveground symptoms that resemble those caused by potato purple top and psyllid yellows diseases (Wallis 1955; Munyaneza et al. 2007a, b, 2008). At present, applications of insecticides targeted against the potato psyllid are the only means to effectively manage ZC (Goolsby et al. 2007; Berry et al. 2009; Gharalari et al. 2009; Butler et al. 2011). Identification and development of potato varieties with resistance to or tolerance of $\mathrm{ZC}$ are crucial to developing effective and sustainable management strategies for this important potato disease. The objective of this research was to screen commonly used potato cultivars for ZC susceptibility, by exposing potato plants to liberibacter-infective potato psyllids under controlled field cage conditions.

\section{Materials and Methods}

\section{Field Screening Experimental Design}

In each of the 2009 and 2010 potato growing seasons, nine potato cultivars commonly grown in the United States were evaluated for susceptibility to ZC under controlled field cage conditions at the USDA-ARS research farm at Moxee in WA. Both fresh and processing potato cultivars were evaluated. The varieties screened were Russet Burbank, Ranger Russet, Umatilla Russet, Russet Norkotah, Alturas, Shepody, Atlantic, FL1867, and FL1879; the last two are Frito-Lay proprietary potato varieties. Potato plants were inoculated with " $\mathrm{Ca}$. L. solanacearum" by exposing them to liberibacter-infective potato psyllids and monitoring them for ZC symptom development. The psyllids were from a liberibacter-infective colony that was established and maintained at the USDA-ARS facility in Wapato, WA with psyllids collected from ZC-infected experimental potato plots in Weslaco, TX in 2007; the insects were continuously reared on potato plants for several generations and tested for liberibacter on a regular basis by polymerase chain reaction (PCR) assay.

Small field cages (Munyaneza et al. 2008) were used to confine potato psyllids on the potato plants and to exclude other potato pests. The soil at the study site is sandy loam and was treated with pre-plant herbicides S-ethyl dipropylthicarbamate (Eptam; Gowan Company, Yuma, AZ) and trifluralin (Treflan; Dow Agrociences, LLC, Calgary, AB) at recommended label rates prior to planting. Additional weeding was done by hand as needed throughout the season. The individual plot under each cage measured $1.8 \mathrm{~m}$ long by $1 \mathrm{~m}$ wide and was designed to accommodate up to eight potato plants. Within each cage, the ground was hilled into a mound $\sim 0.3 \mathrm{~m}$ high. The frame of each cage was formed by inserting both ends of two $3 \mathrm{~m}$-long fiberglass poles (Geotek, Inc. Stewartville, MN) into the ground at opposite ends of each plot, to form hoops over the mounds. A third fiberglass pole was placed halfway between the outside poles forming a central support. Insect proof fabric, Econet SF (USGR, Inc. Seattle, WA), $3 \mathrm{~m}$ wide and $4.6 \mathrm{~m}$ long, was draped over the frame of each cage and the edges were buried in the ground. Each cage was spaced approx. $2.5 \mathrm{~m}$ from the next one endwise and a spacing of $2 \mathrm{~m}$ was placed between rows of cages. In both years, potato planting took place in the last week of May. Six whole potato seed tubers were planted per cage with a spacing of $23 \mathrm{~cm}$ between seed pieces and planted at a depth of $13 \mathrm{~cm}$. Fertilizer Simplot Grower Solutions 16-1616 (Simplot Grower Solutions, Halsey, OR) was sidedressed at the time of planting at a rate of $37.4 \mathrm{~g} /$ plot. Drip tape irrigation (Queen Gil, Intl. Burgas, Bulgaria) was used throughout the season to water the potatoes as needed. 
For each variety screened, there were a total of 6 cages with plants in 3 cages being exposed to 20 potato psyllid adults per plant whereas the plants in the other remaining 3 cages were left psyllid-free to serve as controls. The cages were arranged in a randomized complete block design. The experimental design was the same for each growing season. The plants were exposed to psyllids at the potato tuber initiation stage by releasing the insects near the base of each potato plant in each cage. This plant stage was selected to ensure tuber production and to allow for visual assessment of $\mathrm{ZC}$ symptoms in the tubers. At the time of insect release on the potato plants, liberibacter infection rate in psyllids ranged between $80 \%$ and $100 \%$ in both years. The psyllids were eliminated from the plants a week following insect exposure by spraying plants with an insecticide mixture of thiamethoxam (Actara; Syngenta, Greensboro, NC), acetamiprid (Assail; DuPont, Tokyo, Japan), and spiromesifen (Oberon; Bayer Cropscience, Research Triangle Park, NC) at recommended label rates. This insecticide mixture was selected to ensure that all life stages of the potato psyllid were eliminated. A similar follow-up spray was done after 5 days to ensure complete elimination of the insects. Following the insect removal, plants in the cages were monitored for aboveground $\mathrm{ZC}$ plant symptoms and the experiment was terminated when all the plants in the cages had senesced. At the end of the experiment, the plants in each cage were individually hand-harvested and tubers from each plant checked for ZC symptoms to estimate disease incidence. Also, potato tuber yield was measured for all plants in each cage. For each cultivar, yield loss was calculated by comparing average yield of the inoculated plants per cage to that of control plants. In addition, tuber samples were collected from each cage and processed into fried chips according to Munyaneza et al. (2008) to further confirm disease infection. A plant was considered diseased if at least one tuber from the plant had typical ZC symptoms either in raw or fried chips. Furthermore, to confirm " $\mathrm{Ca}$. L. solanacearum" infection, potato plant and tuber tissues were randomly collected from two plants in each cage and tested for liberibacter by PCR.

\section{Liberibacter Testing}

DNA Extraction for Insects Total DNA was extracted from potato psyllids using CTAB buffer extraction (Zhang et al. 1998; Munyaneza et al. 2010b) but without grinding in liquid nitrogen. Using a micropestle, individual psyllids were ground in $1.5 \mathrm{~mL}$ sample tubes (Eppendorf North America, Hauppauge, NY) in $500 \mu \mathrm{l}$ of CTAB buffer $(2 \%$ CTAB, $1.4 \mathrm{M} \mathrm{NaCl}, 20$ mM EDTA, $100 \mathrm{mM}$ Tris-HCl, $\mathrm{pH}$
8.0 , and $0.2 \%$ mercaptoethanol). The samples were incubated for $30 \mathrm{~min}$ at $65^{\circ} \mathrm{C}$. The samples were maintained at room temperature for $3 \mathrm{~min}$ and then $500 \mu \mathrm{l}$ of ice-cold chloroform was added. Samples were vortexed and then centrifuged at $14,000 \mathrm{rpm}$ for $10 \mathrm{~min}$. The aqueous layer was then transferred to a new microfuge tube containing 0.6 volume of isopropanol and $1 \mu \mathrm{l}$ of glycogen. The tube was placed on ice for $20 \mathrm{~min}$ to precipitate DNA. DNA was recovered by centrifugation as described above. The pellet was washed with ice-cold $70 \%$ ethanol and centrifuged at $14,000 \mathrm{rpm}$ for $2 \mathrm{~min}$ and the pellet was air-dried. The pellet was resuspended in $50 \mu \mathrm{l}$ of sterile water.

DNA Extraction for Plants Total DNA was extracted from potato plant material using a modified version of the CTAB buffer extraction method of Pastrik and Maiss (2000). DNA was extracted from potato tissues using the procedure described below. Five hundred $\mathrm{mg}$ of potato tissue (petioles, stolons, and/or tubers) was macerated in $1 \mathrm{~mL}$ of extraction buffer $(100 \mathrm{mM}$ Tris- $\mathrm{HCl}, \mathrm{pH} 8.0,50 \mathrm{mM}$ EDTA, $500 \mathrm{mM} \mathrm{NaCl}, 10 \mathrm{mM}$ mercaptoethanol) using BioReba sample bags and a semi-automated, ball-bearing grinding Homex 6 homogenizer (BioReba, Switzerland). Potato tissue macerate $(300 \mu \mathrm{l})$ was mixed with $80 \mu \mathrm{l}$ lysozyme $(50 \mathrm{mg} / \mathrm{ml}$ in $10 \mathrm{mM}$ Tris- $\mathrm{HCl}, \mathrm{pH}$ 8.0; SigmaAldrich, Inc., St Louis, MO) and incubated for $30 \mathrm{~min}$ at $37^{\circ} \mathrm{C}$. After incubation, $500 \mu \mathrm{l}$ CTAB buffer $(2 \% \mathrm{CTAB}$, $1.4 \mathrm{M} \mathrm{NaCl}, 20 \mathrm{mM}$ EDTA, $100 \mathrm{mM}$ Tris-HCl, pH 8.0, $0.2 \%$ mercaptoethanol) was added to the homogenate and the sample was incubated for $30 \mathrm{~min}$ at $65^{\circ} \mathrm{C}$. The sample was then placed at room temperature for $3 \mathrm{~min}$ before the addition of $500 \mu \mathrm{l}$ of ice cold chloroform. Samples were vortexed to mix, then centrifuged at $14,000 \mathrm{rpm}$ for $10 \mathrm{~min}$. The aqueous layer was then transferred to a new microfuge tube and 0.6 volume of isopropanol was added and tube was placed on ice for $20 \mathrm{~min}$ to precipitate DNA. DNA was recovered by centrifugation as above. Pellet was washed with ice cold $70 \%$ ethanol and centrifuged at 14,000 rpm for $2 \mathrm{~min}$. After removal of ethanol, the pellet was air dried then re-suspended in $100 \mu \mathrm{l}$ sterile water.

Detection of Liberibacter with PCR Detection of "Ca. L. solanacearum" was performed with primer pair OA2/OI2c (Crosslin and Munyaneza 2009; Liefting et al. 2008, 2009). Briefly, PCR was performed with $50 \mu$ reactions containing $1 \mathrm{X}$ Green GoTaq reaction buffer (Promega), $100 \mathrm{uM}$ dNTPs, 20 pmol of each primer, $2 \mu$ of DNA extracts, and $1 \mathrm{U}$ of GoTaq Polymerase (Promega). The PCR cycling conditions were $94^{\circ} \mathrm{C}$ for 2 min followed by 40 cycles at $94^{\circ} \mathrm{C}$ for $30 \mathrm{~s}, 65^{\circ} \mathrm{C}$ for $30 \mathrm{~s}$, and $72^{\circ} \mathrm{C}$ for $60 \mathrm{~s}$ followed by a final incubation at $72^{\circ} \mathrm{C}$ for $5 \mathrm{~min}$ (MJ Research). Ten $\mathrm{ml}$ of the reactions were analyzed by electrophoresis in $1.5 \%$ agarose gels, stained with ethidium bromide, and observed 
under ultraviolet light. Presence of the predicted 1,168 bp 16S rDNA band indicated samples were positive for " $\mathrm{Ca}$. L. solanacearum".

\section{Statistical Analysis}

Due to high ZC incidence in the plants and lack of variation in both years of the study, no statistical analysis was performed for disease incidence. However, analysis of variance was performed for potato yield loss among the different cultivars in each year. The analysis of variance was performed by using SAS general linear models procedures (SAS Institute 2003). The level of significance was set at $P=0.05$ and the Tukey's student range (HSD) test was used to separate means.

\section{Results and Discussion}

Breeding of ZC-resistant or tolerant varieties using traditional approaches or genetic engineering may offer the most efficient and sustainable way to manage $\mathrm{ZC}$, especially potato varieties that discourage vector feeding. During the present study, all the commercially available potato varieties evaluated in both 2009 and 2010 were very susceptible to ZC, with almost $100 \%$ of plants developing severe ZC foliar and tuber symptoms (Table 1). PCR testing of the exposed plants confirmed presence of liberibacter, with average infection rates of $65.8 \%$ and $74.2 \%$ in 2009 and 2010 , respectively. No liberibacter was detected in potato plants or tubers from control plots. The reasons behind the discrepancies in visual assessment of ZC symptoms and results of conventional PCR testing of the plant and tuber material observed during this study are unknown but may be due to low titer of liberibacter in ZC-infected potato tubers. Quantitative real-time PCR detection for " $\mathrm{Ca}$. L. solanacearum" in different parts of ZC-infected potato plant material has shown this bacterium to have an uneven distribution in planta (Li et al. 2009), often making PCR detection of this bacterium in potato plants and tubers inconsistent. Potato yield in all tested varieties was significantly affected by ZC as well, with average yield loss ranging from $49.9 \%$ to $87.2 \%$ depending on the growing season (Table 1). In 2009, Umatilla Russet and FL1867 suffered less yield loss compared to other cultivars evaluated, whereas the same observation was made for Ranger Russet and again FL1867 in 2010. However, FL1867 was significantly and consistently the least affected as to potato yield loss compared to other tested cultivars over both years of the study (Table 1). These observations suggest that FL1867 may be tolerant to ZC to some extent. It is worth noting that potato cultivars for fresh market were affected by the disease as much as those used for both chip and fry processing. Despite production of tubers in the inoculated potato plants, the quality of fried chips processed from these tubers was severely affected and commercially unacceptable, making all the produced potato tubers unmarketable.

Since its first documentation in 1994 in potatoes growing near Saltillo, Mexico and subsequent initial records in potato fields in southern Texas in 2000 (Secor and Rivera-Varas 2004; Secor et al. 2009), ZC has caused considerable damage to potato production. The potato industry in Texas estimates that ZC could affect over $35 \%$ of the potato acreage in Texas, with potential losses annually to growers exceeding 25 million dollars (CNAS 2006). Fields of potatoes infected with $\mathrm{ZC}$ have also been documented in several other states, including Nebraska, Colorado, Kansas, Wyoming, New Mexico, Arizona, Nevada, and California (Munyaneza et al. 2007a, b; Secor et al. 2009; Crosslin et al. 2010; Munyaneza 2010). In addition, the disease has caused millions of dollars in losses to potato growers in Mexico, Guatemala, and Honduras (Secor and Rivera-Varas 2004; Rubio-Covarrubias et al. 2006; Munyaneza et al. 2007a, b, 2009; Secor et al. 2009;
Table 1 Zebra chip incidence and yield loss in selected fresh and processing potato cultivars exposed to liberibacter-infective psyllids under controlled field cage conditions. The study was conducted at the USDA-ARS research farm at Moxee, WA. A plant was considered diseased if at least one tuber from the plant had typical ZC symptoms either in raw or fried chips

${ }^{\mathrm{a}}$ Means followed by the same letter within columns are not significantly different $(P>0.05$; HSD)

\begin{tabular}{llllll}
\hline Cultivar & \multicolumn{2}{l}{ Average ZC incidence in plants $(\%)$} & & \multicolumn{2}{l}{ Average yield loss (\%) } \\
\cline { 2 - 3 } \cline { 5 - 6 } & 2009 & & 2009 & 2010 \\
\hline Alturas & 82.5 & 100 & & $87.2 \pm 0.8 \mathrm{a}$ & $63.4 \pm 3.1 \mathrm{a}$ \\
Ranger Russet & 100 & 100 & & $74.1 \pm 1.5 \mathrm{a}$ & $53.4 \pm 0.7 \mathrm{~b}$ \\
Russet Burbank & 100 & 100 & & $86.6 \pm 0.6 \mathrm{a}$ & $63.0 \pm 1.2 \mathrm{a}$ \\
Russet Norkotah & 100 & 100 & & $63.4 \pm 2.5 \mathrm{a}$ & $62.7 \pm 0.8 \mathrm{a}$ \\
Umatilla Russet & 100 & 100 & & $89.9 \pm 2.2 \mathrm{~b}$ & $62.1 \pm 0.9 \mathrm{a}$ \\
Shepody & 100 & 100 & & $73.8 \pm 0.4 \mathrm{a}$ & $58.4 \pm 1.5 \mathrm{a}$ \\
Atlantic & 100 & 100 & & $55.5 \pm 0.9 \mathrm{~b}$ & $53.2 \pm 0.4 \mathrm{~b}$ \\
FL1867 & 89 & 100 & $61.7 \pm 0.5 \mathrm{a}$ & $62.0 \pm 1.2 \mathrm{a}$ \\
FL1879 & 100 & 100 & &
\end{tabular}


Crosslin et al. 2010; Rehman et al. 2010). In some regions, entire fields have been abandoned because of ZC (Secor and Rivera-Varas 2004; Munyaneza et al. 2007a; Crosslin et al. 2010). With the recent introduction of the potato psyllid in New Zealand (Gill 2006), ZC is estimated to have caused some 50 million dollars worth of damage to the potato industry in the 2008-2009 growing seasons alone (Liefting et al. 2008, 2009; Teulon et al. 2009).

Currently, vigorous pest control programs that rely heavily on use of conventional insecticides targeted against the potato psyllid are the only means to manage ZC (Goolsby et al. 2007; Berry et al. 2009; Gharalari et al. 2009; Butler et al. 2011). Unfortunately, substantial increases in the quantities of insecticides applied against this pest in some potato growing regions not only have led to higher costs to growers but also to environmental concerns and increased opportunity for the development of resistance by the psyllid. In addition, it was recently determined that groups of 20 potato psyllids per plant successfully transmitted liberibacter to potato and caused $\mathrm{ZC}$ after an inoculation access period of $1 \mathrm{~h}$, whereas it took about $6 \mathrm{~h}$ for a single psyllid per plant to do the same (Buchman 2011; Buchman et al. 2011). This observed short inoculation access period for both multiple and single psyllids represents a substantial challenge for growers in controlling this insect vector. Just a few infective-psyllids feeding on potato for short periods could result in substantial spread of the disease within a potato field or region. Most importantly, pesticides may have limited disease control as they may not kill the potato psyllid fast enough to prevent liberibacter transmission to potato. However, some conventional and biorational pesticides, including plant extracts, mineral oils and kaolin, have shown some substantial deterrence and repellency effects to potato psyllid feeding and oviposition (Gharalari et al. 2009; Yang et al. 2010; Butler et al. 2011; Lacey et al. 2011; Peng et al. 2011) and could be useful tools in integrated pest management programs to manage ZC and its psyllid vector. Nonetheless, identification and development of host plant resistance to $\mathrm{ZC}$ could provide the most effective and sustainable means to manage this potato disease.

Although none of the potato varieties evaluated during the present study appeared immune to ZC, preliminary results of ongoing $\mathrm{ZC}$ screening trials of advanced potato breeding lines suggest that some of these lines appear to exhibit substantial tolerance to ZC, liberibacter, and/or psyllid feeding and warrant further investigation. These potato breeding lines include those with germplasm derived from wild Solanum species that have been shown to exhibit resistance to many insect pests of potato (Munyaneza et al. 2010a; Novy et al. 2010). A more extensive screening of these promising breeding lines is crucial to identification of resistant or tolerant potato material to $\mathrm{ZC}$.
In summary, host plant resistance to " $\mathrm{Ca}$. Liberibacter solanacearum" and its insect vector could be a major component of an integrated approach for managing ZC. Unfortunately, to date, it appears that important cultivars currently being used in potato production are susceptible to $\mathrm{ZC}$, although there may be varying levels of susceptibility. While the name "zebra chip" appears to imply that the disease is only limited to chipping potato cultivars, results of the current study clearly demonstrated that all types of potatoes were severely affected by ZC. Ultimately, information from this research suggests that there is an urgent need for developing and evaluating new potato varieties that are resistant or tolerant to this damaging potato disease.

Acknowledgements We are grateful to Blaine Heilman, Millie Heidt, and Jerry Gefre for their invaluable technical assistance. Financial support for this work was partially provided by Frito Lay, Inc., USDA-ARS State Cooperative Potato Research Program, Texas Department of Agriculture, USDA-RAMP (Project \# 2009-5110105892) and USDA-SCRI (Project \#2009-51181-20176).

\section{References}

Berry, N.A., M.K. Walker, and R.C. Butler. 2009. Laboratory studies to determine the efficacy of selected insecticides on tomato/ potato psyllid. New Zealand Plant Protection 62: 145-151.

Buchman, J.L. 2011. Vector efficiency of the potato psyllid, Bactericera cockerelli (Šulc), in zebra chip disease epidemiology: The effects of life stage, inoculation access period and vector density. M.S. Thesis, Washington State University, Pullman, WA.

Buchman, J.L., V.G. Sengoda, and J.E. Munyaneza. 2011. Vector transmission efficiency of liberibacter by Bactericera cockerelli (Hemiptera: Triozidae) in zebra chip potato disease: effects of psyllid life stage and inoculation access period. Journal of Economic Entomology (in press).

Butler, C.D., F.R. Byrne, M.L. Keremane, R.F. Lee, and J.T. Trumble. 2011. Effects of insecticides on behavior of adult Bactericera cockerelli (Hemiptera: Triozidae) and transmission of Candidatus Liberibacter psyllaurous. Journal of Economic Entomology 104: 586-594.

CNAS. 2006. Economic impacts of zebra chip on the Texas potato industry. Center for North American Studies. http://cnas.tamu. edu/zebra\%20chip\%20impacts\%20final.pdf.

Crosslin, J.M., and J.E. Munyaneza. 2009. Evidence that the zebra chip disease and the putative causal agent can be maintained in potatoes by grafting and in vitro. American Journal of Potato Research 86: 183-187.

Crosslin, J.M., J.E. Munyaneza, J.K. Brown, and L.W. Liefting. 2010. Potato zebra chip disease: a phytopathological tale. Online. Plant Health Progress. doi:10.1094/PHP-2010-0317-01-RV.

Gharalari, A.H., C. Nansen, D.S. Lawson, J. Gilley, J.E. Munyaneza, and K. Vaughn. 2009. Knockdown mortality, repellency, and residual effects of insecticides for control of adult Bactericera cockerelli (Hemiptera: Psyllidae). Journal of Economic Entomology 102: 1032-1038.

Gill, G. 2006. Tomato psyllid detected in New Zealand. Biosecurity New Zealand 69: 10-11.

Goolsby, J.A., J. Adamczyk, B. Bextine, D. Lin, J.E. Munyaneza, and G. Bester. 2007. Development of an IPM program for management of the potato psyllid to reduce incidence of Zebra Chip disorder in potatoes. Subtropical Plant Science 59: 85-94. 
Hansen, A.K., J.T. Trumble, R. Stouthamer, and T.D. Paine. 2008. A new huanglongbing species, 'Candidatus Liberibacter psyllaurous' found to infect tomato and potato, is vectored by the Psyllid Bactericera cockerelli (Sulc). Applied and Environmental Microbiology 74: 5862-5865.

Lacey, L.A., T.X. Liu, J.L. Buchman, J.E. Munyaneza, J.A. Goolsby, and D.R. Horton. 2011. Entomopathogenic Fungi (Hypocreales) for control of potato psyllid, Bactericera cockerelli (Šulc) (Hemiptera: Triozidae) in an area endemic for zebra chip disease of potato. Biological Control 56: 271-278.

Li, W., J.A. Abad, R.D. French-Monar, J. Rascoe, A. Wen, N.C. Gudmestad, G.A. Secor, I.M. Lee, Y. Duan, and L. Levy. 2009. Multiplex real-time PCR for detection, identification and quantification of 'Candidatus Liberibacter solanacearum' in potato plants with zebra chip. Journal of Microbiological Methods 78: $59-65$.

Liefting, L.W., Z.C. Rez-Egusquiza, G.R.G. Clover, and J.A.D. Anderson. 2008. A new 'Candidatus Liberibacter' species in Solanum tuberosum in New Zealand. Plant Disease 92: 1474.

Liefting, L.W., B.S. Weir, S.R. Pennycook, and G.R.G. Clover. 2009. 'Candidatus Liberibacter solanacearum', associated with plants in the family Solanaceae. International Journal of Systematic and Evolutionary Microbiology 59: 2274-2276.

Miles, G.P., M.A. Samuel, J. Chen, E.L. Civerolo, and J.E. Munyaneza. 2010. Evidence that cell death is associated with zebra chip disease in potato tubers. American Journal of Potato Research 87: 337-349.

Munyaneza, J.E. 2010. Psyllids as vectors of emerging bacterial diseases of annual crops. Southwestern Entomologist 35: 417477.

Munyaneza, J.E., J.M. Crosslin, and J.E. Upton. 2007a. Association of Bactericera cockerelli (Homoptera: Psyllidae) with "zebra chip", a new potato disease in southwestern United States and Mexico. Journal of Economic Entomology 100: 656-663.

Munyaneza, J.E., J.A. Goolsby, J.M. Crosslin, and J.E. Upton. $2007 \mathrm{~b}$. Further evidence that zebra chip potato disease in the lower Rio Grande Valley of Texas is associated with Bactericera cockerelli. Subtropical Plant Science 59: 30-37.

Munyaneza, J.E., J.L. Buchman, J.E. Upton, J.A. Goolsby, J.M. Crosslin, G. Bester, G.P. Miles, and V.G. Sengoda. 2008. Impact of different potato psyllid populations on zebra chip disease incidence, severity, and potato yield. Subtropical Plant Science 60: 27-37.

Munyaneza, J.E., V.G. Sengoda, J.M. Crosslin, G. De la Rosa-Lozano, and A. Sanchez. 2009. First report of 'Candidatus Liberibacter psyllaurous' in potato tubers with zebra chip disease in Mexico. Plant Disease 93: 552.

Munyaneza, J.E., Buchman, J.L., Sengoda, V.G., Fisher, T.W., Bester, G., Hoopes, R., Miller, C., Novy, R., Van Hest, P., and J. Nordgaard. 2010a. Potato variety screening trial for zebra chip resistance under controlled field cage conditions. In: F. Workneh and C.M. Rush (eds.), Proceedings of the 10th Annual Zebra Chip Reporting Session, pp. 200-203. Dallas, TX.
Munyaneza, J.E., T.W. Fisher, V.G. Sengoda, S.F. Garczynski, A. Nissinen, and A. Lemmetty. 2010b. Association of "Candidatus Liberibacter solanacearum" with the psyllid Trioza apicalis (Homoptera: Triozidae) in Europe. Journal of Economic Entomology 103: 1060-1070.

Novy, R.G., Whitworth, J., Alvarez, J., Trumble, J.T., Butler, C., Buchman, J.L., and J.E. Munyaneza. 2010. Unique tri-species germplasm with multiple insect resistances and its use in breeding for resistance to psyllid/zebra chip. In: F. Workneh and C.M. Rush (eds.), Proceedings of the 10th Annual Zebra Chip Reporting Session, pp. 103-105. Dallas, TX.

Pastrik, K.H., and E. Maiss. 2000. Detection of Ralstonia solanacearum in potato tubers by polymerase chain reaction. Journal of Phytopathology 148: 619-626.

Peng, L., J.T. Trumble, J.E. Munyaneza, and T.-X. Liu. 2011. Repellency of a kaolin particle film to potato psyllid, Bactericera cockerelli (Hemiptera: Psyllidae), on tomato under laboratory and field conditions. Pest Management Science 67: 815-824.

Rehman, M., J. Melgar, C. Rivera, N. Urbina, A.M. Idris, and J.K. Brown. 2010. First report of "Candidatus Liberibacter psyllaurous" or "Ca. Liberibacter solanacearum" associated with severe foliar chlorosis, curling, and necrosis and tuber discoloration of potato plants in Honduras. Plant Disease 94: 376.

Rubio-Covarrubias, O.A., I.H. Almeyda-Leon, J.I. Moreno, J.A. Sanchez-Salas, R.F. Sosa, J.T. Borbon-Soto, C.D. Hernandez, J. A. Garzon-Tiznado, R.R. Rodriguez, and M.A. Cadena-Hinajosa. 2006. Distribution of potato purple top and Bactericera cockerelli Sulc. in the main potato production zones in Mexico. Agricultura Técnica en México 32: 201-211.

SAS Institute. 2003. SAS user's guide: statistics, version 9.1. Cary, NC.

Secor, G.A., and V. Rivera-Varas. 2004. Emerging diseases of cultivated potato and their impact on Latin America. Revista Latinoamericana de la Papa (Suplemento) 1: 1-8.

Secor, G.A., V. Rivera-Varas, J.A. Abad, I.-M. Lee, G.R.G. Clover, L. W. Liefting, X. Li, and S.H. De Boer. 2009. Association of 'Candidatus Liberibacter solanacearum' with zebra chip disease of potato established by graft and psyllid transmission, electron microscopy, and PCR. Plant Disease 93: 574-583.

Teulon, D.A.J., P.J. Workman, K.L. Thomas, and M.-C. Nielsen. 2009. Bactericera cockerelli: incursion, dispersal and current distribution on vegetable crops in New Zealand. New Zealand Plant Protection 62: 136-144.

Wallis, R.L. 1955. Ecological studies on the potato psyllid as a pest of potatoes. USDA Technical Bulletin 1107.

Yang, X.-B., Y.-M. Zhang, L. Hau, L.-N. Peng, J.E. Munyaneza, and T.-X. Liu. 2010. Repellency of selected biorational insecticides to potato psyllid, Bactericera cockerelli (Hemiptera: Psyllidae). Crop Protection 29: 1320-1324.

Zhang, Y.P., J.K. Uyemoto, and B.C. Kirkpatrick. 1998. A small-scale procedure for extracting nucleic acids from woody plants infected with various phytopathogens for PCR assay. Journal of Virological Methods 71: 45-50. 